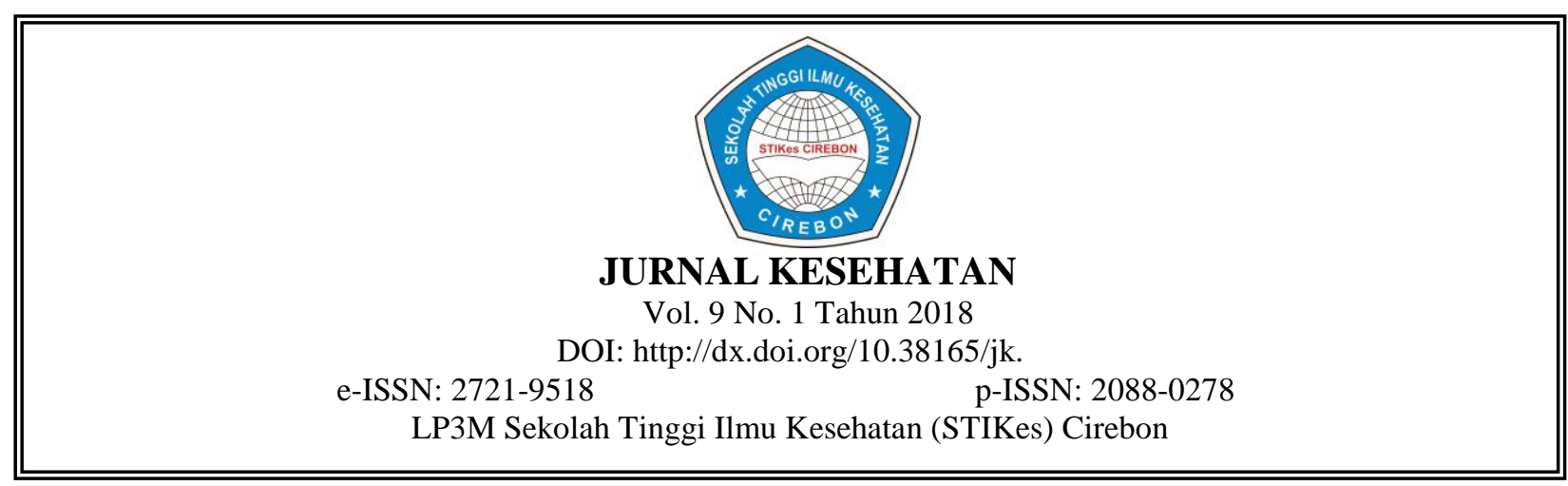

\title{
KUALITAS PENCATATAN ASUHAN KEPERAWATAN KOMUNITAS
}

Diding Sarifudin*
Program Studi Kesehatan Masyarakat, Sekolah Tinggi Ilmu Kesehatan Cirebon
dings_crb@yahoo.co.id

\begin{abstract}
Abstrak
Cakupan kegiatan keperawatan komunitas di Kabupaten Cirebon masih rendah, sedangkan perawat sebagai pelaksananya merupakan tenaga kesehatan terbanyak dibandingkan dengan tenaga kesehatan lainnya. Perawat melakukan asuhan keperawatan komunitas seharusnya dengan pendokummentasian atau pencatatan yang merupakan panduan sehingga kegiatannya terarah dan terpadu sesuai dengan masalah yang ditemukan. Tujuan penelitian ini adalah ingin mengetahui kualitas pencatatan asuhan keperawatan komunitas di Kabupaten Cirebon tahun 2006 dan faktorfaktor yang mempengaruhinya. Penelitian ini adalah penelitian kuantitatif dengan menggunakan rancangan crosssectional. Data dikumpulkan dari 71 perawat puskesmas dengan menggunakan perhitungan besar sampel Lot quality assurance sampling (LQAS-Lot) secara sistematic random sampling, selain dilakukan wawancara juga dilakukan pemeriksaan catatan asuhan keperawatan masing-masing responden 5 dokumen. Penelitian dilakukan pada bulan September 2006 dengan menggunakan analisis univariat dan analisis jalur (path analysis). Dari data yang dikumpulkan diperoleh kualitas pencatatan dengan baik sebesar $59,2 \%$. Hasil pemodelan dengan analisis jalur ternyata kepemimpinan merupakan variabel utama yang mempunyai pengaruh sebesar $46,8 \%$ terhadap kualitas pencatatan asuhan keperawatan, variabel lain yang mempunyai pengaruh terhadap kualitas pencatatan asuhan keperawatan adalah pengetahuan sebesar $31 \%$, sikap sebesar $17,6 \%$, imbalan sebesar $11,6 \%$, dan variabel masa kerja melalui sikap sebesar $4 \%$. Kepemimpinan kepala puskesmas mampu meningkatkan kualitas pencatatan asuhan keperawatan yang dilakukan karyawannya, selain itu kepemimpinan dapat meningkatkan pengetahuan, mengatur imbalan yang diberikan, dan dapat merubah sikap karyawannya. Bagi Dinas Kesehatan yang mempunyai kewajiban membina kepala puskesmas maka harus selalu membina dan mengevaluasi kinerja kepala puskesmas.
\end{abstract}

Kata Kunci: Kualitas pencataan Asuhan Keperawatan

\begin{abstract}
Scope of community nursing activity in district of Cirebon has undervalued. In fact, number of nurse resources there larger than another medical profession. They to be organized in community nursing activity and nursing activity record-keeping as principal guide, they will working in sistematic way and well integrated according to the problem raised from public health service. This research aim to determine the quality of community nursing activity recordkeeping in district of Cirebon for year of 2006 and the influencing factors within. Research belongs to quantitative research with cross-sectional design. Data collecting using Lot quality assurance sampling (LQAS-Lot) with sistematic random sampling method by surveying and interviewing 71 nurses from local public health services, including checking of 5 documents from each respondent's nursing record. Research taken during September 2006 and using univariat analysis and path analysis. The result shows the quality of record-keeping which noticed as good are 52,2 \% in value. Modelling result from path analysis put leadership as main variable which influence the quality of nursing recordkeeping at 46,8\%. Another variable which having influence on quality of nursing record-keeping are nurse's knowledge at $31 \%$, nurse's attitude at 17,6\%, rewards at 11,6\% and working period at 4\%. Leadership skills of local public service's head can improve the quality of record-keeping of community nursing activity by its employees (nurses). Besides, leadership skills direct to improvement of knowledge, remuneration management, and change in attitude. District public health service which has responsibility in training and developing officer to become head of local public health service should control and monitor their working performance continuously.
\end{abstract}

Keyword: quality of community nursing 


\section{PENDAHULUAN}

Dewasa ini Indonesia dihadapkan kepada masalah kesehatan yang sangat kompleks, dimana penyakit infeksi maupun degeneratif secara bersama-sama muncul di masyarakat ${ }^{1}$. Salah satu tugas pokok tenaga perawat di puskesmas adalah melaksanakan asuhan keperawatan komunitas. Keperawatan komunitas atau yang lebih dikenal sebagai perawatan kesehatan masyarakat (Perkesmas) merupakan bagian integral dari pelayanan kesehatan Puskesmas dan subsitem dari pelayanan kesehatan masyarakat. Pada dasarnya Perkesmas adalah sintesa dari ilmu keperawatan dan ilmu kesehatan masyarakat yang didukung oleh berbagai ilmu lainnya. ${ }^{1}$

Selama ini keperawatan komunitas mengalami berbagai kendala terutama dalam memahami konsep serta upaya operasional pelaksanaannya di lapangan. Hal ini mengakibatkan keperawatan komunitas selama bertahun-tahun tidak mendapatkan tempat yang semestinya di dalam tatanan pelayanan kesehatan masyarakat. Kondisi seperti ini diperberat dengan adanya anggapan bahwa keperawatan komunitas tidak efektif dan efisien dalam tatanan pelayanan kesehatan. ${ }^{2}$ Padahal kalau dikaji lebih jauh, apabila pelayanan kesehatan dasar dapat menerapkan konsep keperawatan komunitas secara benar maka pelayanan kesehatan akan menjadi lebih baik yang terpusat pada layanan promotif dan preventif secara berkesinambungan dan komprehensif sesuai dengan paradigma sehat. $^{3}$

Pelayanan keperawatan komunitas diharapkan dapat memberikan bantuan, bimbingan, penyuluhan, pengawasan dan perlindungan kepada individu, keluarga, kelompok khusus serta masyarakat. Bantuan yang diberikan untuk memecahkan masalah kesehatan yang dihadapi yang diakibatkan karena faktor ketidaktahuan, ketidakmauan ataupun karena faktor ketidakmampuan dengan menggunakan metoda proses keperawatan. Dalam memberikan pelayanan asuhan keperawatan dengan pendekatan proses keperawatan, harus disertai dengan pendokumentasian dalam bentuk rencana perawatan yang dimulai dari tahap pengkajian sampai tahap evaluasi dengan mencatat perkembangannya. ${ }^{2}$

Berdasarkan laporan tahunan Dinas Kesehatan Kabupaten Cirebon selama tiga tahun berturutturut memang terjadi kenaikan cakupan pelayanan keperawatan komunitas (tahun 2003: 20\%, tahun 2004: 32\%, tahun 2005: 43\%) tetapi masih jauh di bawah target Depkes yaitu 80\%. Semestinya program keperawatan komunitas ini dapat berjalan karena secara kuantitas tenaga keperawatan merupakan tenaga yang paling banyak : 47,28\% dari seluruh tenaga kesehatan, dan dari jumlah tersebut diantaranya $48,84 \%$ bekerja di puskesmas. ${ }^{4}$ Di Kabupaten Cirebon tenaga perawat yang bekerja di puskesmas berjumlah 548 orang $(39,83 \%)$ dari tenaga kesehatan yang ada di puskesmas dengan jumlah 1.376 orang. Dari 548 tenaga perawat di puskesmas diantaranya yang masih berpendidikan SPK sebanyak 181 orang $(33,03 \%)$.

Banyak faktor yang mempengaruhi kinerja perawat dalam melakukan asuhan keperawatan. Hal ini sesuai dengan yang dikemukakan oleh Gibson ${ }^{5}$ bahwa ada tiga variabel yang mempengaruhi perilaku dan prestasi, yaitu : variabel individu (kemampuan dan keterampilan : mental fisik, latar belakang: keluarga, tingkat sosial, pengalaman, demografis : umur, asal usul, jenis kelamin), variabel psikologi (persepsi, sikap, kepribadian, belajar, motivasi), variabel organisasi (sumber daya, kepemimpinan, imbalan, struktur, desain pekerjaan).

Perawat merupakan tenaga kesehatan terdepan yang memberikan pelayanan kesehatan kepada masyarakat sehingga kinerja perawat puskesmas turut menentukan kinerja puskesmas secara keseluruhan. ${ }^{4}$ Selain tenaga yang cukup, juga tersedia sumber daya yang lain seperti dana transport kunjungan (seharusnya tersedia) dan format asuhan keperawatan.

Apabila keperawatan komunitas dilaksanakan secara benar, terarah dan terpadu dengan kegiatan pokok puskesmas lain yang terkait diharapkan akan memberikan kontribusi pada upaya untuk meningkatkan derajat kesehatan dan untuk mengurangi kesenjangan jangkauan pelayanan kesehatan. $^{2}$ Pelayanan keperawatan komunitas harus disertai dengan pendokumentasian atau pencatatan dalam bentuk rencana perawatan. Pendokumentasian ini sangat penting karena pencatatan ini dipergunakan sebagai pedoman untuk melakukan tindakan keperawatan kepada 
sasaran (individu, keluarga, kelompok atau masyarakat), sebagai bahan penilaian pegawai fungsional yang dikenal dengan kredit point, dan sebagai legal hukum atau bukti otentik jika suatu saat terjadi hal-hal yang tidak diinginkan.

Jika sebagian besar atau semua perawat dengan berbagai latar belakang pendidikan dan pengalaman melakukan asuhan keperawatan maka pertanyaannya bagaimana kualitasnya? Karena apabila pelayanan asuhan keperawatan komunitas dilakukan asal-asalan maka hasil yang dirasakan masyarakat dengan masalah kesehatan yang membutuhkan bantuan tenaga kesehatan menjadi tidak optimal atau hanya buang-buang tenaga, waktu dan biaya saja. Tujuan penelitian untuk mengetahui 'Kualitas Pencatatan Asuhan Keperawatan Komunitas Di Kabupaten Cirebon Tahun 2006”.

\section{METODE PENELITIAN}

Penelitian ini adalah penelitian kuantitatif dengan menggunakan rancangan cross-sectional karena variabel dependen (kualitas pencatatan asuhan keperawatan komunitas) dan variabel independen (pendidikan, pelatihan, pengetahuan, lama bekerja, sikap, karakteristik puskesmas, sarana, dana, imbalan, kepemimpinan, monitoring dan evaluasi) dilakukan pengamatan pada waktu yang sama. Penelitian ini dilakukan di Puskesmas wilayah Kabupaten Cirebon, sedangkan waktu penelitian dilaksanakan pada bulan September 2006.

Populasi pada penelitian ini adalah semua perawat yang bekerja di puskesmas di wilayah Kabupaten Cirebon yang menghasilkan dokumen/catatan asuhan keperawatan komuni-tas yaitu sebanyak 548 orang. Besar sampel yang dibutuhkan berdasarkan perhitungan dengan metode Lot quality assurance sampling (LQAS-Lot) adalah sebanyak 64 perawat ditambah $10 \%$ (7 orang) sehingga jumlahnya 71 perawat, dan pemeriksaan dokumennya masing-masing perawat 5 dokumen sehingga berjumlah 355 dokumen. Pengambilannya dilakukan secara sistematik random sampling.

Alat pengumpul data pada penelitian ini adalah menggunakan kuesioner dalam bentuk pertanyaan tertutup dan pertanyaan terbuka. Sedangkan untuk mengukur atau menilai kualitas pencatatan asuhan keperawatannya (variabel dependen) menggunakan check list sebagai pedoman pemeriksaan terhadap dokumen/catatan asuhan keperawatan.

Analisis dilakukan mulai analisis univariat yang dilakukan adalah masing-masing variabel mulai variable dependen dan kemudian variabel independen, kemudian analisis jalur (Path Analysis) menurut Sarwono Jonathan ${ }^{6}$ adalah bagian analisis regresi yang digunakan untuk menganalisis hubungan kausal antar variabel, di mana variabel-variabel bebas mempengaruhi variabel terikat baik secara langsung maupun tidak langsung, melalui satu atau lebih variabel perantara.

\section{HASIL PENELITIAN}

Hasil penelitian tentang kualitas pencatatan asuhan keperawatan komunitas di Kabupaten Cirebon tahun 2006, ternyata responden yang mempunyai kualitas pencatatan baik lebih banyak dibandingkan dengan yang mempunyai kualitas pencatatan buruk, yaitu kualitas pencatatan baik sebanyak 42 orang $(59,2 \%)$ dan kualitas pencatatan buruk sebanyak 29 orang $(40,8 \%)$.

Penilaian kualitas pencatatan dilihat dari pendokumentasian asuhan keperawatan komunitas di puskesmas yang terdiri dari beberapa bagian dokumentasi yang tidak lain adalah proses keperawatan diantaranya pengkajian pada keluarga dan individu, pembuatan genogram dan denah rumah, analisis dengan prioritas masalahnya, rencana perawatan, implementasi dan evaluasi tindakan, serta penilaian tingkat kemandirian keluarga. Pengkajian pada keluarga ternyata responden yang sudah melakukan dengan baik/lengkap sebanyak 40 orang $(56,3 \%)$, responden yang sudah melakukan pengkajian pada individu dengan baik/lengkap sebanyak 38 orang (53,5\%). Pembuatan genogram dan denah rumah pada saat pengkajian sering dilupakan atau ditinggalkan oleh petugas terbukti dari hasil penelitian yang membuat genogram dan denah rumah sebanyak 31 orang $(43,7 \%)$. Langkah analisis merupakan langkah penting dalam asuhan keperawatan untuk menentukan masalah yang muncul, tetapi langkah ini sering dilewatkan langsung ke langkah berikutnya, dari hasil penelitianpun menunjukan hal yang sama yaitu yang melakukan analisis dengan baik hanya 12 orang (16,9\%) saja. Setelah langkah menentukan masalah dan 
memprioritaskannya maka langkah selanjutnya adalah membuat rencana perawatan berdasarkan diagnosis perawatan, responden yang sudah melakukan rencana perawatan dengan baik hanya 34 orang (47,9\%). Langkah implementasi lebih baik dibandingkan langkah-langkah yang lain, seperti hasil penelitian menunjukan yang sudah melakukan langkah implementasi dengan baik sebanyak 43 orang $(60,6 \%)$. Langkah terakhir adalah langkah menilai sejauh mana tingkat kemandirian keluarga dalam mengatasi masalah kesehatan yang dihadapi, responden yang sudah menilai tingkat kemandirian keluarga dengan baik sebanyak 29 orang $(40,8 \%)$.

Berdasarkan pendidikan keperawatan yang telah ditamatkan oleh responden di Kabupaten Cirebon tahun 2006; sebagian besar mempunyai pendidikan D3 Keperawatan yaitu sebanyak 45 orang $(63,4 \%)$, dan yang mempunyai pendidikan SPK (Sekolah Perawat Kesehatan) sebanyak 26 orang $(36,6 \%)$, tidak ada yang mempunyai pendidikan S1 Keperawatan.

Setiap tahun mulai tahun 2003 sampai dengan tahun 2006 di Kabupaten Cirebon telah dilakukan pelatihan asuhan keperawatan komunitas, tetapi ternyata dari hasil penelitian masih banyak yang belum mengikuti pelatihan yaitu sebanyak 24 orang $(33,8 \%)$, yang menyatakan pernah mengikuti pelatihan sebanyak 47 orang $(66,2 \%)$ dan diantaranya adalah yang mengikuti pelatihan pada tahun 2006 sebesar $73 \%$.

Penilaian pengetahuan berdasarkan kemampuan responden menjawab pertanyaan sekitar keperawatan komunitas, dan hasilnya menunjukan 38 orang $(53,5 \%)$ dinyatakan mempunyai pengetahuan buruk tentang keperawatan komunitas dan 33 orang $(46,5 \%)$ dinyatakan mempunyai pengetahuan baik.

Distribusi lama bekerja responden di puskesmas sangat bervariasi, mulai 0 tahun (1 orang) sampai dengan 28 tahun dengan simpangan baku 6,8 tahun, paling banyak lama bekerja adalah 2 tahun dengan rata-rata lama bekerja 6,5 tahun, nilai ini sangat dipengaruhi oleh seorang responden yang mempunyai masa bekerja paling lama yaitu 28 tahun dan dua orang yang mempunyai masa kerja 26 tahun.

Pernyataan atau penilaian evaluatif responden terhadap pelaksanaan keperawatan komunitas yang dinyatakan dengan persetujuan terhadap penilaian tersebut, maka dari hasil penelitian terlihat responden yang mempunyai sikap positif lebih banyak dibandingkan dengan sikap negatif, yang mempunyai sikap positif sebanyak 42 orang $(59,2 \%)$ dan yang mempunyai sikap negatif sebanyak 29 orang $(40,8 \%)$.

Di Kabupaten Cirebon terdapat 4 puskesmas percontohan yaitu Puskesmas Astanajapura, Puskesmas Mundu, Puskesmas Cirebon Selatan dan Puskesmas Weru dari 53 puskesmas yang ada, responden yang terambil sebagai sampel yang berasal dari puskesmas percontohan sebanyak 5 orang $(7 \%)$ dari jumlah sampel 71 orang.

Sarana yang terdiri dari ketersediaan isntrumen (PHN kit) dan format pengkajian (family folder) sebagai kelengkapan penunjang pelaksanaan asuhan keperawatan komunitas. Responden yang menyatakan tersedia sarana tersebut sebanyak 47 orang $(66,2 \%)$ dan yang menyatakan tidak tersedia sebanyak 24 orang $(33,8 \%)$.

Dana merupakan faktor pendukung suatu kegiatan, ketersediaan biaya tersebut sangat mempengaruhi berjalan tidaknya kegiatan. Dalam pelaksanaan keperawatan komunitaspun hampir sama, seorang pimpinan akan kesulitan menggerakan karyawannya apabila tidak didukung dengan ketersediaan dana tersebut. Dana yang dimaksud adalah ketersediaan biaya untuk transportasi kunjungan rumah dari berbagai sumber, menurut responden yang menyatakan tersedia dana di puskesmasnya masing-masing untuk pelaksanaan asuhan keperawatan komunitas sebanyak 31 orang $(43,7 \%)$ dan yang menyatakan tidak tersedia sebanyak 40 orang $(56,3 \%)$.

Insentif berupa uang atau bentuk lain yang diterima oleh responden setelah melaksanakan asuhan keperawatan di luar gaji pokok hanya sebagian kecil saja yang menyatakan ada atau pernah diberikan insentif tersebut yaitu sebanyak 25 orang $(35,2 \%)$ dan yang menyatakan tidak ada imbalan apapun setelah melaksanakan asuhan keperawatan komunitas sebanyak 46 orang $(64,8 \%)$.

Pelaksana asuhan keperawatan komunitas sangat dipengaruhi oleh faktor kepemimpinan kepala puskesmas, di sini kepala puskesmas diuji kemampuan dan keterampilannya untuk 
mempengaruhi, menggerakan dan merubah perilaku karyawan terutama dalam hal pelaksanaan keperawatan komunitas. $46(64,8 \%)$ responden menyatakan kepemimpinan kepala puskesmas baik dalam asuhan keperawatan komunitas dan 25 (35,2\%) menyatakan buruk atau kurang baik.

Monitoring dan evaluasi atau supervisi yang dilakukan oleh kepala puskesmas dan Dinas Kesehatan Kabupaten Cirebon terhadap petugas dalam pelaksanaan keperawatan komunitas, menurut responden seimbang antara monitoring evaluasi baik dan kurang baik atau buruk, responden yang menyatakan monitoring dan evaluasi baik sebanyak 41 orang $(57,7 \%)$ dan yang menyatakan kurang baik atau buruk sebanyak 30 orang $(42,3 \%)$.

Setelah mendapatkan nilai koefisien jalur kemudian dibuatkan model atau memperbaiki model yang telah dibuat pada kerangka konsep dengan menggunakan model Trimming yaitu model yang digunakan untuk memperbaiki suatu model struktur analisis jalur dengan cara mengeluarkan dari model variabel eksogen (bebas) yang koefisien jalurnya tidak signifikan. Cara menggunakan model Trimming yaitu dengan menghitung ulang koefisien jalur tanpa menyertakan variabel eksogen (bebas) yang koefisien jalurnya tidak signifikan.

Model Struktur Empiris Final Pengaruh Variabel Bebas Terhadap Variabel Terikat:

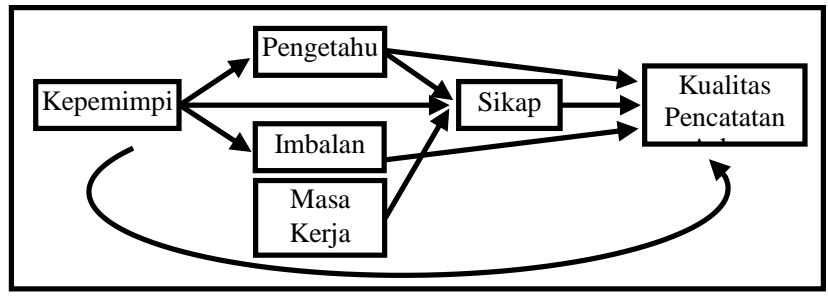

Dari hasil akhir analisis jalur Pengaruh langsung variabel kepemimpinan terhadap pengetahuan sebesar 0,395 , pengaruh langsung variabel kepemimpinan terhadap imbalan sebesar 0,157 .

Pengaruh langsung variabel kepemimpinan terhadap variabel sikap sebesar 0,235, pengaruh variabel kepemimpinan terhadap variabel sikap melalui pengetahuan sebesar 0,159 , pengaruh total variabel kepemimpinan terhadap variabel sikap sebesar 0,394, pengaruh langsung variabel pengetahuan terhadap variabel sikap sebesar 0,402, pengaruh langsung variabel masa kerja terhadap variabel sikap sebesar 0,227 , pengaruh gabungan antara variabel X1,4,9 terhadap variabel sikap (Y) sebesar 0,274.

Pengaruh langsung variabel kepemimpinan terhadap kualitas pencatatan asuhan keperawatan komunitas sebesar 0,468, pengaruh langsung variabel pengetahuan terhadap kualitas pencatatan asuhan keperawatan komunitas sebesar 0,310, pengaruh langsung variabel imbalan terhadap kualitas pencatatan asuhan keperawatan komunitas sebesar 0,116, pengaruh langsung variabel sikap terhadap kualitas pencatatan asuhan keperawatan komunitas sebesar 0,176 , pengaruh variabel kepemimpinan terhadap kualitas pencatatan asuhan keperawatan komunitas melalui variabel pengetahuan sebesar 0,122 , pengaruh variabel kepemimpinan terhadap kualitas pencatatan asuhan keperawatan komunitas melalui variabel imbalan sebesar 0,018, pengaruh variabel kepemimpinan terhadap kualitas pencatatan asuhan keperawat-an komunitas melalui variabel sikap sebesar 0,041, pengaruh variabel kepemimpinan terhadap kualitas pencatatan asuhan keperawatan komunitas melalui variabel pengetahuan dan sikap sebesar 0,028 , pengaruh total variabel kepemimpinan terhadap kualitas pencatatan asuhan keperawatan komunitas sebesar 0,678, pengaruh langsung variabel pengetahuan terhadap kualitas pencatatan asuhan keperawatan komunitas sebesar 0,310, pengaruh variabel pengetahuan terhadap kualitas pencatatan asuhan keperawatan komunitas melalui variabel sikap sebesar 0,071, pengaruh total variabel pengetahuan terhadap kualitas pencatatan asuhan keperawatan komunitas sebesar 0,381, pengaruh langsung variabel imbalan terhadap kualitas pencatatan asuhan keperawatan komunitas sebesar 0,116, pengaruh variabel masa kerja terhadap kualitas pencatatan asuhan keperawatan komunitas melalui 
variabel sikap sebesar 0,040 , pengaruh langsung variabel sikap terhadap kualitas pencatatan asuhan keperawatan komunitas sebesar 0,176, pengaruh gabungan variabel X1,4.,6,9 dan sikap (Y) terhadap Kualitas pencatatan asuhan keperawatan komunitas (Z) sebesar 0,657

\section{PEMBAHASAN}

Penilaian kualitas pencatatan dilihat dari pendokumentasian asuhan keperawatan komunitas di puskesmas yang terdiri dari beberapa bagian dokumentasi yang tidak lain adalah proses keperawatan diantaranya pengkajian pada keluarga dan individu, pembuatan genogram dan denah rumah, analisis dengan prioritas masalahnya, rencana perawatan, implementasi dan evaluasi tindakan, serta penilaian tingkat kemandirian keluarga. Dokumentasi asuhan keperawatan yang telah dibuat oleh perawat dibandingkan dengan standar yang seharusnya diisi pada masing-masing langkah asuhan keperawatan, sehingga bisa diketahui kekurangan (mempunyai kualitas yang kurang baik) dalam pengisian atau pembuatan dokumentasi asuhan keperawatan. Seperti diketahui yang dimaksud dengan standar adalah suatu kesepakatan tertulis yang isinya spesifikasi teknis atau kriteria lain yang persis untuk dipergunakan secara konsisten sebagai aturan-aturan pedoman atau mendefinisikan produk untuk memastikan bahwa semua bahan baku, proses dan pelayanan sesuai dengan tujuan. ${ }^{7}$ Pengertian lain tentang standar adalah hasil konsensus semua pihak yang terkait dengan suatu jasa pelayanan termasuk pasien, dan menjamin keseragaman spesifikasi teknis minimal yang harus dipenuhi. ${ }^{8}$ Penerapan standar secara benar akan melindungi pasien dari pelayanan kesehatan yang diberikan dengan mutu rendah yang dapat berakibat fatal. Standar juga dapat melindungi pemberi pelayanan kesehatan serta mempermudah dalam pelayanan karena terdeskripsikan secara jelas.

Dengan melakukan penilaian ini sama dengan melihat sejauh mana tingkat kepatuhan petugas kesehatan terhadap standar yang seharusnya. Hasil penelitian Tamzil, 2004 kepatuhan perawat terhadap SOP pelayanan rawat inap sebesar 85\%. Tentang mutu proses diketahui dari hasil pengamatan langsung atau review dari catatan dan informasi yang merupakan rekonstruksi yang cermat, apa yang lebih kurang terjadi. Menjaga mutu pelayanan kesehatan pada sisi proses pelayanan kesehatan, berhubungan secara langsung dengan praktek keperawatan dengan pasien. Sejak pengkajian, penetapan diagnosis keperawatan, penetapan rencana tindakan, implementasi tindakan keperawatan yang direncanakan dan tahap evaluasi, apakah telah mengacu pada standar dan prosedur pelayanan yang ditetapkan secara profesional. Kepatuhan perawat dalam memberikan asuhan keperawatan mengacu kepada standar dan prosedur tersebut sangat mempengaruhi mutu pelayanan kesehatan terhadap pasien. Dalam menilai apakah asuhan keperawatan yang diberikan bermutu atau tidak (kepatuhan terhadap standar pelayanan) dapat dilakukan oleh atasan atau teman sejawat (peer review) atau tim yang ditugasi, atau bahkan melalui laporan keluhan pasien. Dengan menggunakan instrumen-instrumen yang disediakan seperti daftar tilik (check list), kuesioner, wawancara dan sebagainya.

Kepatuhan/konformitas adalah berubahnya pandangan atau tindakan seorang individu sebagai akibat dari tekanan kelompok yang muncul karena adanya pertentangan antara pendapat si individu dengan pendapat kelompok. ${ }^{9}$ Konformitas dapat terjadi jika sasaran individu sesuai dengan nilai budaya atau norma sosial kelompoknya. ${ }^{9}$ Individu-individu yang bersikap sedemikian rupa ini biasanya sangat sukar diubah sikapnya karena merasa bersatu dengan kelompok sosialnya meskipun tidak selalu berarti bahwa mereka mempunyai kekuasaan di kelompok itu. Menurut Kelman. ${ }^{9}$ perubahan sikap dan perilaku individu dimulai dengan tahap kepatuhan, identifikasi, kemudian baru menjadi internalisasi. Mula-mula individu mematuhi anjuran/instruksi Kepala Dinas Kesehatan tanpa kerelaan untuk melakukan tindakan tersebut dan sering kali karena ingin menghindari hukuman/sangsi jika dia tidak patuh, atau untuk memperoleh imbalan yang dijanjikan jika dia mematuhi anjuran tersebut. Biasanya perubahan yang terjadi dalam tahap kepatuhan ini sifatnya sementara, artinya bahwa tindakan itu dilakukan selama masih ada pengawasan. Tetapi begitu pengawasan itu mengendur/hilang, perilaku itupun ditinggalkan. Menurut Kelman selanjutnya, pengawasan itu tidak perlu berupa kehadiran fisik petugas atau tokoh otoriter, melainkan cukup rasa 
takut terhadap ancaman sangsi yang berlaku, jika individu tidak melakukan tindakan tersebut. Dalam tahap ini pengaruh tekanan kelompok sangatlah besar. Individu terpaksa mengalah dan mengikuti perilaku mayoritas kelompok meskipun sebenarnya dia tidak menyetujuinya. Namun segera setelah dia keluar dari kelompok tersebut, mungkin sekali perilakunya akan berubah menjadi perilaku yang diinginkannya sendiri. Kepatuhan individu yang berdasarkan rasa terpaksa atau ketidakpahaman tentang pentingnya perilaku yang baru itu, dapat disusul dengan kepatuhan yang berbeda jenisnya yaitu kepatuhan demi menjaga hubungan baik dengan yang menganjurkan perubahan tersebut. Perubahan perilaku individu baru dapat menjadi optimal jika perubahan tersebut terjadi melalui proses internalisasi di mana perilaku yang baru itu dianggap bernilai positif bagi diri individu itu sendiri dan diintegrasikan dengan nilai-nilai lain dari hidupnya.

\section{Kepemimpinan terhadap Kualitas Pencatatan Asuhan Keperawatan}

Variabel kepemimpinan merupakan variabel yang paling besar mempengaruhi kualitas pencatatan asuhan keperawatan komunitas di Kabupaten Cirebon. Variabel kepemimpinan ini merupakan variabel utama yang mempengaruhi kualitas pencatatan asuhan keperawatan komunitas karena di samping sebagai variabel yang paling besar mempengaruhi juga karena variabel lain yang mempengaruhi secara langsung terhadap kualitas pencatatan asuhan keperawatan dipengaruhi oleh faktor kepemimpinan seperti faktor pengetahuan, imbalan dan sikap. Sehingga kalau ingin kualitas pencatatan asuhan keperawatan lebih baik maka faktor kepemimpinan kepala puskesmas yang harus sangat diperhatikan.

Walaupun latar belakang pendidikan kepala puskesmas bukan dari keperawatan atau dengan kata lain kepala puskesmas kurang memahami keperawatan komunitas tetapi dengan fungsinya sebagai pemimpin yang harus mampu memotivasi, menjadi inspirator bagi karyawan maka kepala

puskesmas harus mampu mendayagunakan sumber daya yang ada. Sumber daya manusia merupakan prioritas utama untuk diberdayakan, dengan keterbatasan baik dari kuantitas maupun kualitas. Untuk meningkatkan kualitas pencatatan asuhan keperawatan komunitas maka kepala puskesmas harus mampu :

1. Meningkatkan pengetahuan perawat dalam pelaksanaan keperawatan komunitas seperti dijelaskan di atas.

2. Merubah sikap perawat tentang keperawatan komunitas terutama perawat yang mempunyai masa kerja yang lama karena dari hasil penelitian diperoleh hubungan atau korelasi negatif tanpa mengabaikan perawat-perawat muda.

3. Mengatur pendanaan yang ada di puskesmas untuk memberikan imbalan kepada perawat yang telah melakukan keperawatan komunitas dengan baik walaupun imbalan atau penghargaan tidak hanya dalam bentuk dana tetapi bisa juga dengan ucapan terima kasih atau pujian kepada perawat yang telah melakukan keperawatan komunitas dengan baik.

4. Menunjukan kepedulian dan perhatian terhadap pelaksanaan keperawatan komunitas dengan melakukan evaluasi secara khusus baik formal dalam pertemuan atau tidak formal, melakukan diskusi-diskusi tentang keperawatan komunitas, seperti yang dikemukakan Baldrige ${ }^{10}$ bahwa tinjauan kinerja yang dilakukan secara teratur memungkinkan pemimpin senior memonitor kinerja dan kemajuan-kemajuan yang dicapai, sehingga secara efektif akan diketahui kebutuhan perusahaan untuk menyesuaikan dengan perubahan yang terjadi di lingkungan bisnis.

Kemampuan kepemimpinan kepala puskesmas dalam mengatur dan mendayagunakan sumber daya yang ada di puskesmas dan lingkungan sekitarnya sangat diperlukan sehingga pelaksanaan keperawatan komunitas dapat berjalan dan pencatatan asuhan keperawatannya mempunyai kualitas yang baik. Sistem kepemimpinan yang efektif menurut Baldrige ${ }^{10}$ yaitu menghargai kapabilitas dan persyaratan karyawan serta stakeholder lainnya. Ia juga menetapkan ekspektasi tinggi terhadap kinerja dan perbaikan kinerja. Sistem kepemimpinan yang efektif membangun loyalitas dan kerja tim berdasarkan nilai-nilai organisasi dalam hal ini adalah puskesmas dan upaya pencapaian tujuan bersama. Ia mendorong dan mendukung inisiatif dan pengambilan resiko yang pantas, membawahi struktur organisasi untuk tujuan dan fungsi, menghindari rantai komando yang panjang dalam 
membuat keputusan. Sistem kepemimpinan yang efektif termasuk mekanisme pemimpin menjalankan pengujian diri sendiri, menerima umpan balik dan memperbaiki diri.

Kepala puskesmas harus mampu menerapkan sistem manajemen yang baik tentang kegiatan keperawatan komunitas dengan sumber daya yang ada yaitu mulai dari perencanaan, pelaksanaan dan evaluasi.

Puskesmas harus menyediakan pelayanan yang sesuai dan bermanfaat serta memiliki kebijakan peningkatan kesejahteraan, kepuasan dan motivasi pegawai, yang mengatur semuanya itu adalah pimpinan puskesmas. Seorang kepala puskesmas harus memastikan terciptanya strategi, sistem, dan metode untuk mencapai kinerja yang baik, mendorong inovasi dan meningkatkan pegetahuan serta kapabilitas puskesmas yang dipimpinnya, sesuai dengan yang dikemukakan Baldrige $^{10}$ bahwa keberhasilan untuk mencapai kinerja yang ekselen juga didukung oleh sistem yang mampu mendorong fleksibilitas, inovasi, pertukaran pengetahuan atau keterampilan, keselarasan kerja dengan sasaran perusahaan, fokus pada pelanggan, dan memiliki respon yang cepat terhadap perubahan bisnis dan persyaratan pasar.

Dijelaskan lagi bahwa pemimpin senior secara perorangan harus terlibat dalam tindakan perbaikan kinerja. Porsi waktu yang signifikan harus digunakan untuk aktifitas perbaikan kinerja ini. Hal ini semestinya harus tercermin dalam tindakan-tindakan nyata misalnya dalam penetapan sasaran, perencanaan dan pengakuan serta penghargaan terhadap pencapaian kinerja dan keberhasilan perbaikan proses.

Memimpin bersifat personal dan impersonal, walaupun perencanaan dan pengorganisasian menyediakan petunjuk dan pengarahan tetapi orang-oranglah yang melaksanakan pekerjaan itu, dan orang biasanya tidak dapat diduga, mereka mempunyai kebutuhan, aspirasi, kepribadian, dan sikap yang unik. ${ }^{5}$ Pemimpin harus memperhitungkan persepsi dan perilaku yang unik ini dengan cara tertentu untuk diarahkan menuju tujuan bersama yang telah ditetapkan.

\section{Pengetahuan terhadap Kualitas Pencatatan Asuhan Keperawatan}

Hasil penelitian menemukan bahwa variabel pengetahuan baik secara langsung mapun tidak langsung melalui variabel sikap mempengaruhi kualitas pencatatan asuhan keperawatan komunitas. Seperti yang telah dijelaskan di atas bahwa pengetahuan merupakan proses penginderaaan sehingga orang menjadi tahu bagaimana melakukan asuhan keperawatan komunitas dengan baik. Banyak cara orang atau perawat menjadi tahu tentang keperawatan komunitas bisa melalui pendidikan dan pelatihan, membaca teori-teori atau pedoman-pedoman keperawatan komunitas, melihat atau memperhatikan teman kerja melakukan asuhan keperawatan komunitas, atau karena dorongan dari pimpinannya. Menurut Gibson ${ }^{5}$ bahwa tambahan pengetahuan baru yang signifikan akan menyebabkan terjadinya perubahan yang lebih cepat dibandingkan sebelumnya. Tiga sumber utama pembelajaran dan pertumbuhan perusahaan datang dari manusia, sistem, dan prosedur perusahaan, tujuan finansial, pelanggan, dan proses bisnis internal, di Balanced Scorecard biasanya akan memperlihatkan adanya kesenjangan antara kapabilitas sumber daya manusia, sistem dan prosedur saat ini dengan apa yang dibutuhkan untuk menghasilkan kinerja yang penuh terobosan. ${ }^{11}$

Karena pengetahuan mempengaruhi kualitas pencatatan asuhan keperawatan komunitas, maka untuk memperbaiki kualitas berarti harus ada penambahan pengetahuan perawat tentang keperawatan komunitas. Perubahan atau penambahan pengetahuan bisa berasal dari diri sendiri (internal) dengan kata lain ada keinginan perawat untuk meningkatkan pengetahuannya, bisa juga berasal dari luar individu perawat misalnya karena peraturan atau dorongan dari pimpinan atau kelompoknya. Sehingga dengan meningkatnya pengetahuan tentang pelaksanaan keperawatan komunitas maka perawat akan melaksanakan asuhan keperawatan sesuai dengan ketentuan yang ditetapkan. 


\section{Imbalan terhadap Kualitas Pencatatan Asuhan Keperawatan}

Hasil penelitian menemukan bahwa imbalan mempengaruhi kualitas pencatatan asuhan keperawatan komunitas di Kabupaten Cirebon, imbalan di sini bisa dalam bentuk uang atau penghargaan lainnya berkaitan dengan hasil kerja perawat yaitu pelaksanaan asuhan keperawatan yang didokumentasikan dengan baik. Hasil penelitian ini mendukung dan sesuai dengan yang dikemukakan oleh Gibson ${ }^{5}$ bahwa salah satu pengaruh yang paling kuat atas prestasi individu ialah sistem imbalan dalam organisasi.

Sejalan pula dengan konsep Baldrige ${ }^{10}$; hal-hal yang berkaitan dengan pelanggan, kinerja, dan keuangan merupakan hal utama yang digunakan dalam penentuan prioritas untuk perbaikan organisasi. Kemudian menyebutkan juga bahwa sekali perusahaan (puskesmas) menetapkan sasaran kinerja utama, perusahaan tersebut harus meninjau sistem kompensasi, penghargaan, dan pengakuan untuk menjamin dukungan pegawai pada pencapaian sasaran strategis perusahaan. Pelanggan menentukan nasib perusahaan (puskesmas), keberadaan perusahaan dan kemampuannya untuk bertahan tergantung pada kemampuannya menghasilkan nilai-nilai yang bermanfaat atau dirasakan bermanfaat oleh pelanggan. Pelanggan yang dimaksud adalah pelanggan internal yaitu karyawan puskesmas dalam hal ini adalah perawat dan pelanggan eksternal yaitu pasien yang menggunakan pelayanan puskesmas.

Puskesmas perlu menyediakan sistem penghargaan terhadap karyawan yang berprestasi, pengaturannya dilakukan oleh kepala puskesmas. Menurut Kaplan ${ }^{11}$ menyebutkan bahwa persoalannya bukan apakah perlu atau tidak tetapi kapan dan bagaimana hubungan itu seharusnya diciptakan. BSC menawarkan pendekatan alternatif untuk menetapkan kapan kompensasi insentif dibayarkan. Pimpinan dapat menetapkan ambang batas minimum untuk semua atau bagian-bagian yang penting, batasan ini harus memotivasi kinerja yang seimbang pada perspektif finansial, pelanggan, proses bisnis internal serta pembelajaran dan pertumbuhan. Pertimbangan lebih lanjut muncul dari kesadaran bahwa kompensasi insentif adalah sebuah contoh dari motivasi ekstrinsik, di mana pekerja bertindak karena akan diberi imbalan untuk pencapaian target yang telah ditentukan dengan jelas.

Sehubungan hal di atas, kalau kita ingin pelaksanaan keperawatan komunitas berjalan dengan baik mempunyai pencatatan asuhan keperawatan dengan baik pula maka puskesmas dalam hal ini pengaturannya dilakukan oleh kepala puskesmas harus menyediakan sistem penghargaan terhadap hasil kerja karyawan

\section{Sikap terhadap Kualitas Pencatatan Asuhan Keperawatan}

Seperti dijelaskan di atas bahwa sikap merupakan gejala dari rangsangan yang datang dari luar, dan sikap melibatkan pikiran, perasaan, dan perhatian seperti dijelaskan Notoatmodjo $^{12}$ sikap adalah respon tertutup seseorang terhadap stimulus atau objek tertentu yang sudah melibatkan faktor pendapat dan emosi yang bersangkutan. Dalam kata lain, fungsi sikap belum merupakan tindakan (reaksi terbuka) atau aktifitas, akan tetapi merupakan predisposisi perilaku (tindakan) atau reaksi tertutup. Hal ini terbukti dari hasil penelitian yang menemukan bahwa sikap mempengaruhi hasil kerja yaitu asuhan keperawatan komunitas. Hasil penelitian ini memperkuat yang dikemukakan Gibson ${ }^{5}$ bahwa Sikap merupakan faktor penentu perilaku, karena sikap berhubungan dengan persepsi, kepribadian dan motivasi.

Karena sikap merupakan gejala dari rangsangan yang datang dari luar, maka kalau kita ingin merubah sikap perawat, faktor yang mempengaruhinya kita perbaiki. Hasil penelitian menemukan tiga faktor yang mempengaruhi sikap perawat pada pelaksanaan keperawatan komunitas yaitu kepemimpinan kepala puskesmas, pengetahuan perawatnya sendiri, dan masa kerja perawat. Dengan memperbaiki faktor luar maka sikap perawat akan berubah (muncul perasaan tertarik terhadap pelaksanaan keperawatan komunitas) dari sikap negatif menjadi sikap positif sehingga kualitas pencatatan asuhan keperawatanpun akan berubah menjadi lebih baik. 


\section{SIMPULAN}

1. Dokumentasi atau pencatatan asuhan keperawatan komunitas di Kabupaten Cirebon yang mempunyai kualitas baik sebesar 59,2\% dan yang mempunyai kualitas buruk sebesar 40,8\%.

2. Pengaruh kepemimpinan kepala puskesmas, pengetahuan, imbalan, masa kerja dan sikap perawat secara gabungan terhadap kualitas pencatatan keperawatan komunitas, mendukung hipotesis 1 tetapi untuk variabel pendidikan, pelatihan, karakteristik puskesmas, dana, sarana dan monev tidak mempunyai hubungan atau pengaruh terhadap kualitas pencatatan asuhan keperawatan komunitas.

3. Pengaruh terbesar terhadap kualitas pencatatan keperawatan komunitas adalah kepemimpinan baik pengaruh langsung maupun tidak langsung, mendukung hipotesis 4 dan hipotesis 5 .

4. Ada pengaruh pengetahuan terhadap kualitas pencatatan keperawatan komunitas baik pengaruh langsung maupun tidak langsung, mendukung hipotesis 4 dan hipotesis 5.

5. Ada pengaruh sikap terhadap kualitas pencatatan keperawatan komunitas, mendukung hipotesis 1 dan hipotesis 4.

6. Ada pengaruh imbalan terhadap kualitas pencatatan keperawatan komunitas, mendukung hipotesis 1 dan hipotesis 4 .

7. Ada pengaruh masa kerja terhadap kualitas pencatatan keperawatan komunitas melalui sikap, mendukung hipotesis 5 .

\section{SARAN}

Bagi Badan Kepegawaian Daerah Kabupaten Cirebon: perlunya peningkatan kemampuan kepemimpinan kepala puskesmas, dengan melakukan pendidikan dan pelatihan kepemimpinan, mengadakan seminar-seminar tentang kepemimpinan.

1. Bagi Dinas Kesehatan Kabupaten Cirebon:

1) Perlunya Dinas Kesehatan Kabupaten Cirebon meningkatkan pembinaan kepada kepala puskesmas, dengan melakukan pertemuan rutin di Dinas Kesehatan setiap minimal tiga bulan sekali.

2) Perlunya melakukan supervisi/monitoring dan evaluasi, dengan cara mengunjungi puskesmas secara teratur dan berkesinambungan.

3) Perlunya penilaian kredit point yang benar-benar sesuai aturan yang berlaku

4) Perlunya pemegang program keperawatan komunitas di Dinas Kesehatan melakukan pembinaan dan bimbingan teknis keperawatan komunitas kepada perawat puskesmas, dengan melakukan diskusi dan pembahasan kasus.

5) Perlunya melakukan pelatihan keperawatan komunitas, dengan memilih materi yang sesuai, metode pembelajaran yang sesuai, pengajar yang kompeten di bidangnya, lamanya waktu sesuai ketentuan pelatihan, melakukan evaluasi dan tindak lanjut pelatihan.

6) Perlunya menyediakan sarana penunjang pelaksanaan keperawatan komunitas, dengan cara menyediakan format asuhan keperawatan sesuai kebutuhan, dan mengadakan PHN kit.

2. Bagi puskesmas:

1) Perlunya melakukan pembinaan kepada karyawan, dengan cara melakukan pertemuan mingguan dan bulanan secara rutin, melakukan diskusi-diskusi tentang pelaksanaan keperawatan komunitas

2) Perlunya kepala puskesmas menunjukan perhatian pada pelaksanaan keperawatan komunitas, dengan cara menanyakan kesulitan-kesulitan yang dihadapi oleh perawat, memberikan penghargaan baik secara lisan dengan pujian atau mengatur anggaran yang ada untuk memberikan imbalan bagi mereka yang telah melakukan asuhan keperawatan dengan baik.

3) Bagi peneliti lain

Penelitian ini mampu menjelaskan $65,7 \%$ pengaruh terhadap kualitas pencatatan asuhan keperawatan komunitas dan menyisakan 34,3\% variabel lain yang tidak terjelaskan. 


\section{DAFTAR PUSTAKA}

1. Departemen Kesehatan RI. Petunjuk pelaksanaan perawatan kesehatan masyarakat. Jakarta; DepKes RI:1998.

2. Departemen Kesehatan RI. Pedoman Kegiatan perawat kesehatan masyarakat. Jakarta; DepKes RI:2004.

3. Departemen Kesehatan RI. Rancangan pedoman promosi kesehatan bagi perawat kesehatan masyarakat. Jakarta; DepKes RI: 2004.

4. Departemen Kesehatan RI. Rancangan pedoman peningkatan kinerja perawat Di Puskesmas. Jakarta;DepKes RI: 2004.

5. Gibson, James L. Organisasi, perilaku-struktur-proses. Jakarta : Erlangga; 1994.

6. Goetsch David et al. Manajemen Mutu Total. Edisi terjemahan, Prentice Hall Inc; 1997

7. Tjiptono, Fandi \& Anastasia Diana. Total quality manajemen. Yogyakarta: Andi Offset; 1998.

8. Wijono, Djoko. Manajemen mutu pelayanan kesehatan. Surabaya: Airlangga University Press; 1999

9. Sarwono, Solita. Sosiologi kesehatan beberapa konsep beserta aplikasinya. Yogyakarta: Gadjah Mada University Press; 1993.

10. Haris, Abdul. 7 pilar perusahaan unggul, implementasi kriteria baldrige untuk meningkatkan kinerja perusahaan. Jakarta: Gramedia Pustaka Utama; 2005.

11. Kaplan. The balanced on the balanced scorecard a critical analysis of some of its assumption. Managemen Accounting Research. Elsevier: Academic Press; 2000.

12. Notoatmodjo, Soekidjo. Promosi kesehatan teori dan aplikasi. Jakarta: Rineka Cipta; 2005. 